\title{
Hemşirelik Öğrencilerinin Mesleki Yeterliklerine Yönelik Girişimler ve Kullanılan Ölçüm Araçları: Bir Literatür İncelemesi
}

\author{
Rukiye BURUCU ${ }^{1}$ (D) Hatice DÖNMEZ ${ }^{2}$ \\ ${ }^{1}$ NEÜ Seydişehir Sağlık Bilimleri Fakültesi, Hemşirelik Bölümü, Konya, Türkiye, rburucu@ hotmail.com \\ ${ }^{2}$ NEÜ Seydişehir Sağlık Bilimleri Fakültesi, Hemşirelik Bölümü, Konya, Türkiye, hbasdonmez@gmail.com
}

\begin{tabular}{|c|c|}
\hline Makale Bilgileri & ÖZ \\
\hline $\begin{array}{l}\text { Makale Geçmişi } \\
\text { Geliş: 13.10.2020 } \\
\text { Kabul: 23.12.2020 } \\
\text { Yayın: 25.04.2021 } \\
\text { Anahtar Kelimeler: } \\
\text { Öğrenme Yöntemleri, } \\
\text { Yeterlik, } \\
\text { Yetkinlik, } \\
\text { Hemşirelik Öğrencisi, } \\
\text { Öğrenci Hemşire. }\end{array}$ & 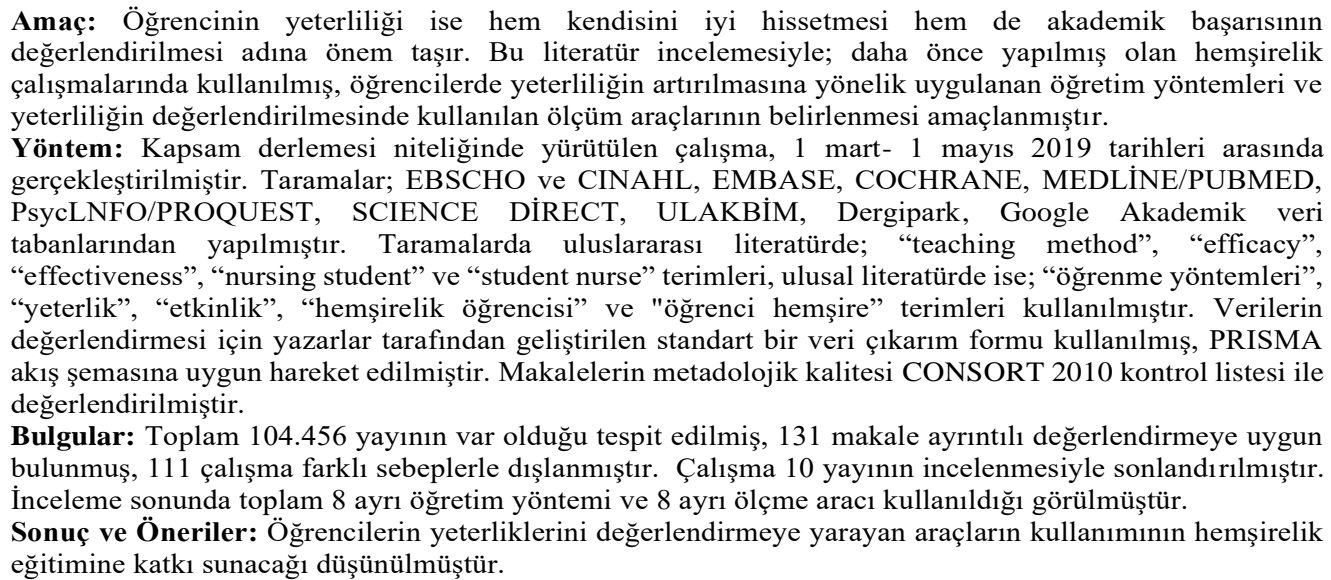 \\
\hline
\end{tabular}

\section{Initiatives for Nursing Students' Professional Competencies and Measurement}

Tools Used: A Literature Review

\section{Article Info}

Article History

Received: 13.10 .2020

Accepted: 23.12.2020

Published: 25.04.2021

Keywords:

Learning Methods,

Proficiency,

Competence,

Nursing Students,

Student Nurses.

\section{ABSTRACT}

Purpose: A students' competency, however, is also important to help them feel good about themselves and in the evaluation of their academic progress. This literature review aims at determining the teaching methods which need to be applied to increase the competence of students and examines the measurement tools used in previous studies of competence assessment.

Method: This scope compilation study was carried out from March 1 to May 1, 2020. The screening was carried out on the following data bases: EBSCHO and CINAHL, EMBASE, COCHRANE, MEDLINE/PUBMED, PsycLNFO/PROQUEST, SCIENCE DIRECT, ULAKBIM, Dergipark, and Google Scholar. The key words used for the screening were "teaching method", "efficacy", "effectiveness", "nursing student" and "student nurse" for international literature and "öğrenme yöntemleri”, “yeterlik", "etkinlik", "hemșirelik öğrencisi” and "öğrenci hemşire" for Turkish literature. A standard data extraction form developed by the authors was used for the evaluation of the data. The study was conducted in line with the PRISMA flow chart and the articles' methodological quality was evaluated with the CONSORT 2010 checklist.

Results: It was determined that there was a total of 104,456 publications, of which 131 were found suitable for detailed examination, and of which 111 were excluded due to various reasons. The study was concluded with the examination of a total of 10 publications. As a result, it was determined that eight different teaching methods and eight different measurement tools were used.

Conclusion and Suggestions: : It was thought that the use of tools to evaluate students' competencies would contribute to nursing education.

Atıf/Citation: Burucu, R., \& Dönmez, H. (2021). Hemşirelik öğrencilerinin mesleki yeterliklerine yönelik girişimler ve kullanılan ölçüm araçları: Bir literatür incelemesi, Genel Să̆lık Bilimleri Dergisi, 3(1), 51-65. 


\section{GİRİŞ}

Yeterlik, Türk Dil Kumu'na göre "yeterlik”, “yetkinlik” anlamı taşımaktadır. Genel olarak bakıldığında ise "Bir işi yapma gücünü sağlayan özel bilgi, ehliyet” olarak açıklanmaktadır (TDK). "Yetkinlik”, “yeterlik”, "yeterlik" terimlerinin literatürde biribiri yerine benzer şekilde kullanılabildiği görülmektedir. Yeterlik, genel anlamda kullanılabildiği gibi pek çok alana özgü farklı yeterlikleri (Akademik, mesleki, genel vs) ifade etmek için de kullanılmaktadır (Arseven, 2016). Bandura'ya göre "Bireyin belli bir performansı göstermek için gerekli etkinlikleri organize edip başarılı olarak yapması" beklenir ve bu durumda birey, "yeterli" olarak kabul edilir (Bandura, 1977). Kişinin kendini yeterli hissetmesi durumu; bireyin öğrenme hızı, görev almaya istekliliği, güçlüklerle baş etme yeteneği ve psikolojik sağlamlığı, iletişimdeki başarısı, motivasyonu, stres ve kaygı durumu, problem çözme ve eleştirel düşünme yeteneği gibi pek çok yönünün gelişmesine katkı sunmaktadır. Bunların tamamı kişinin toplum içinde var olduğu yeri belirleyen önemli özelliklerdir (Pınar et al., 2016; Stayt et al., 2015; Zartman et al., 2002).

Yeterlik kavramı alana yönelik olarak da kullanılmaktadır. Hemşirelikte yeterlik; hemşirelik bakımını güvenli ve etik olarak uygulayabilecek yeterli bilgi, beceri, yetenek ve yargıya sahip olup, farklı koşullarda bile görevini gerçekleştirebilmek olarak açıklanmaktadır (Association, 2018). Hemşirenin yeterli olması ve bu yeterliğinin de öğrenciliğinden itibaren kazandırılmasının önemli olduğu vurgulanmaktadır (Karahan \& Kav, 2018). Bir alandaki yeterlik, farklı yöntemlerle değerlendirilebilmektedir. Öğrencilerin yeterliklerinin değerlendirilmesi hem akademik başarının hem de öğrenmenin yeterliliğini değerlendirmeyi sağlamaktadır. Bunun yanında öğrencinin öğrenmesine de katkı sunmaktadır. Ancak yeterlikler değerlendirilmeden önce, kazanılması beklenen yeterliğe ilişkin uygulanan girişim/kullanılan öğretim yönteminin incelenmesi gerekmektedir (Akın Korhan et al., 2016; George et al., 2017; Grimm \& Fowles, 2018; Henderson et al., 2018; Hong \& Yu, 2017; van Hooft et al., 2018).

Literatüre bakıldığında, hemşirelik öğrencilerinin kendi alanlarındaki yeterliklerinin farklı araçlarla değerlendirildiği görülmektedir (Andrea \& Kotowski, 2017; Ayhan et al., 2018; Bianchi et al., 2020; Edmonson et al., 2016). Genel olarak bu değerlendirmelerin öğrencilerin konuyla ilgili farkındalığına ve öğrenmeye katk1 sunduğu açıklanmaktadır. Öğrencide farkındalığın artmasıyla öğrenmenin arttığı ve öğrendiği zaman da kendini daha yeterli hissettiği belirtilmektedir (Açıksöz et al., 2016; B. Guo et al., 2017; Shinnick \& Woo, 2014; Zhang et al., 2015). Ancak hemşirelik öğrencilerinin yeterliklerinde sınırlılıklar olduğu da belirtilen önemli bir başlıktır (Vanaki et al., 2016). Öğrencilerin alana yönelik yetkin mezun olmaları beklenmekte, bunun sağlanması önerilirken öğrencilerin yetkinliklerinin farklı şekillerde değerlendirilmesi gerektiği de belirtilmektedir (Pınar et al., 2016; Stayt et al., 2015; Zartman et al., 2002). Yetkinliklerin artmasını desteklemek için pek çok ögretim yöntemi kullanılmaktadır. Bunlardan bazıları; similatörlerin kullanılması (Amado Martins et al., 2018; Jonson et al., 2017), standart hasta kullanımı (Andrea \& Kotowski, 2017), farklı psikoterapi tekniklerinin (örn; Pozitif psikoterapi) uygulanması (Layous et al., 2011), teknolojiden destek alınması şeklinde sıralanabilir (Erdoğan \& Bulut, 2017; Lee et al., 2015). Öğrencilerin öğrenmeleri ve yetkinliklerine katkı sunduğu bilinen öğretim yöntemleri ve öğrencilerin yetkinliklerinin değerlendirilmesinde kullanılan araçların incelenmesi literatüre katkı sunacaktır. Bu araştırmada, hemşirelik öğrencilerinde yeterlik durumunun değerlendirildiği randomize kontrollü deneysel çalışmaların (RKD) yer aldığı makalelerin incelenmesiyle; öğrencilerde yeterliğin artırılmasına yönelik uygulanan öğretim yöntemleri ve yeterliğin değerlendirilmesinde kullanılan ölçüm araçlarının belirlenmesi amaçlanmıştır. Araştırmada hedeflenen soru /problem; Hemşirelik öğrencilerinin yeterliklerini artırmak için hangi öğretim yöntemleri uygulanmıştır ve değerlendirmede kullanılan ölçme araçları nelerdir?

\section{YÖNTEM}

$\mathrm{Bu}$ araştırma, literatür incelemesi şeklinde yürütülmüş olup, protokolün oluşturulması ve makalenin yazımında PRISMA bildirimi kullanılmıştır (Karaçam, 2013; Moher et al., 2009)

\section{Tarama stratejisi}

Araştırmanın yürütülmesi ve raporun hazırlanması aşamalarında; Sistematik Derleme ya da Meta Analiz Araştırma Raporunun Yazımında Bulunması Gereken Maddelerle İlgili Kontrol Listesi (PRISMA) rehber alınmıştır 
(Karaçam, 2013; Moher et al., 2009; PRISMA). Araştırmada, bias riskini azaltmak için; literatür taranması, makalelerin seçimi, verilerin çekilmesi ve makale kalitesinin değerlendirilmesi aşamaları her iki araştırmacı tarafından bağımsız olarak yapılmış olup, elde edilen veriler görüş birliği ile birleştirilmiştir. Taramalara başlamadan önce iki araştırmacı "teaching method" anahtar kelimesi ile Science Direct üzerinden örnek bir tarama yapmış ve elde edilen üç makale üzerinde örnek veri çekme ve makale kalitesinin değerlendirilmesi yapılmıştır. Literatür taraması Türkçe ve İngilizce veri tabanlarından, 2010- 2019 tarihlerini kapsayacak şekilde, 1 Mart- 1 Mayıs 2019 tarihleri arasında yapılmıştır. Uluslararası literatürde tarama için; "teaching method", "efficacy", "effectiveness", "nursing student", and "student nurse" anahtar kelimeleri kullanılmıştır. Türkçe literatürde ise; “öğrenme yöntemleri”, “yeterlik”, "etkinlik”, "hemşirelik öğrencisi” ve "öğrenci hemşire” anahtar kelimeleri kullanılmıştır. (Şekil 1). Taramalar; Ebscho ve Cinahl, Embase, Cochrane, Medline/Pubmed, Psyclnfo/Proquest, Scıence Direct, Ulakbim, Dergipark, Google Akademik veri tabanlarında yapılmıştır. Elektronik tarama ile saptanan 104.456 çalışmanın başlıkları değerlendirilmiştir. Elde edilen makalelerin başlık ve özet bölümlerinin incelenmesiyle 131 makale ayrıntılı değerlendirmeye uygun bulunmuştur. Ardından 111 çalışma dahil edilme kriterlerine uygun olmadığı için dışlanmıştır. Makale; 10 yayının incelenmesiyle sonlandırılmıştır. Araştırma PICOS'a göre oluşturulmuştur (Tablo 1). Makalenin yazımı PRISMA protokolüne göre oluşturulmuştur (Karaçam, 2013; Moher et al., 2012; PRISMA) (Şekil 1).

\section{Araştırmaların Seçim Kriterleri ve Seçilmesi}

Dahil edilme kriterleri; çalışmada hemşirelik öğrencilerine yeterliklerini geliştirmek amacıyla bir girişim uygulanmış olması, girişim sonrası öğrenci yeterliğinin bir değerlendirme ölçütü kullanılarak değerlendirilmesi, RKD olması, yayın dilinin İngilizce ya da Türkçe olması, 2010- 2019 tarih aralığında yayınlanmış olması, tam metnine ulaşılabilir olmasıdır (Tablo 1).

Dışlanma kriterleri; çalışmanın tanımlayıcı ve nitel desende yürütülmesi, in-vitro, olgu sunumu, editör yazısı, çalışma protokolü, sistematik derleme ve meta-analiz makalesi olmasıdır.

Tablo 1. PICOS Tablosu

\begin{tabular}{ll}
\hline $\mathrm{P}$ & Hemşirelik eğitimi alan öğrenciler \\
\hline $\mathrm{I}$ & Hemşirelik öğrencilerinin mesleki yeterliklerine yönelik girişim uygulanması \\
\hline $\mathrm{C}$ & Hemşirelik öğrencilerinin mesleki yeterliklerine yönelik girişim uygulanmamış olması \\
\hline 0 & Hemşirelik öğrencilerinde değerlendirilmek istenen yeterlik \\
\hline $\mathrm{S}$ & Randomize kontrollü çalışmalar \\
\hline
\end{tabular}

\section{Verilerin Çekilmesi ve Analizi}

Araştırmacılar tarafından veri çekme aracı oluşturulmuş ve araştırmaya dahil edilen çalışmaların; yöntem, örneklem hacmi, örnek büyüklüğünün belirlenmesi, araştırmanın yapıldığı yer ve yıl, yeterliliği geliştirmek amacıyla uygulanan öğretim yöntemi, sonuç, öneriler başlıkları kontrol edilmiştir. Her araştırmacı makaleleri bu listelerle ayrı ayrı değerlendirdikten sonra veriler birleştirilmiştir. Araştırmacılar kapsama dahil edilecek makalelere fikir birliği ile karar vermiştir. Tarama verileri Tablo 2' de sunulmuştur.

\section{Çalışmaların Metadolojik Kalitesinin Değerlendirilmesi}

Dâhil edilen çalışmalar, metodolojik yönden, iki bağımsız araştırmacı tarafından, 11 sorudan oluşan değerlendirme listesinin Türkçe metni oluşturularak kullanılmıştır. Listeye göre puan verilerek değerlendirme önerilmediği için puanlanma yapılmamıştır (RCT, 2018) (Tablo 2). Makalelerin dokuz tanesi; katılımcılarının sadece hemşirelik öğrencileri olmaması, RKD ve CONSORT verilerine ilişkin yetersizliklerin olması, yayınlanmış çalışma protokolü olması, öğrencinin yeterliliği dışında farklı değerlendirmelerin yapılmış (örn; Öğrenme ortamlarının vs değerlendirilmesi) olması sebebiyle değerlendirmeye alınmamıştır. 


\section{BULGULAR}

\section{Tarama bulguları}

Toplamda tarama alanlarında 104.525 çalışmanın var olduğu tespit edilmiştir. Bunlardan tezler çalışma dışında bırakılmıştır. Yirmidört çalışma tekrar eden kayıt olarak tespit edilmiştir. Toplam 19 RKD’ye ulaşılmıştır. Bunlar dahil edilme kriterlerine göre gözden geçirildiğinde; dokuz makale dışlanmıştır. Bunlardan 3 tanesi araştırma protokolü, 4 tanesi hemşirelik dışındaki alanlardaki öğrenci grupları ile yapılan çalışma makaleleri, 1 tanesi öğrenme ortamının değerlendirildiği bir makale ve 1 tanesi ise tam metne ulaşılamayan bir makaledir. Toplam 10 RKD, araştırma kapsamında değerlendirilmiştir (Tablo 1). Çalışmalarda 8 ayrı öğretim yöntemi uygulandığ 1 ve 8 ayrı ölçme aracı ile yeterliklerin değerlendirildiği görülmüştür. Toplam 10 adet, hemşirelik öğrencisi çalışmasında uygulanan öğretim yöntemi ve kullanılan yeterlik ölçekleri Tablo 3'te verilmiştir.

Taranan veri tabanlarında belirlenen çalışma sayısı (Üniversite toplu tarama motoru) $(n=93)$

\section{Diğer kaynaklardan belirlenen çalışma} sayıs1 $(\mathrm{n}=104.456)$

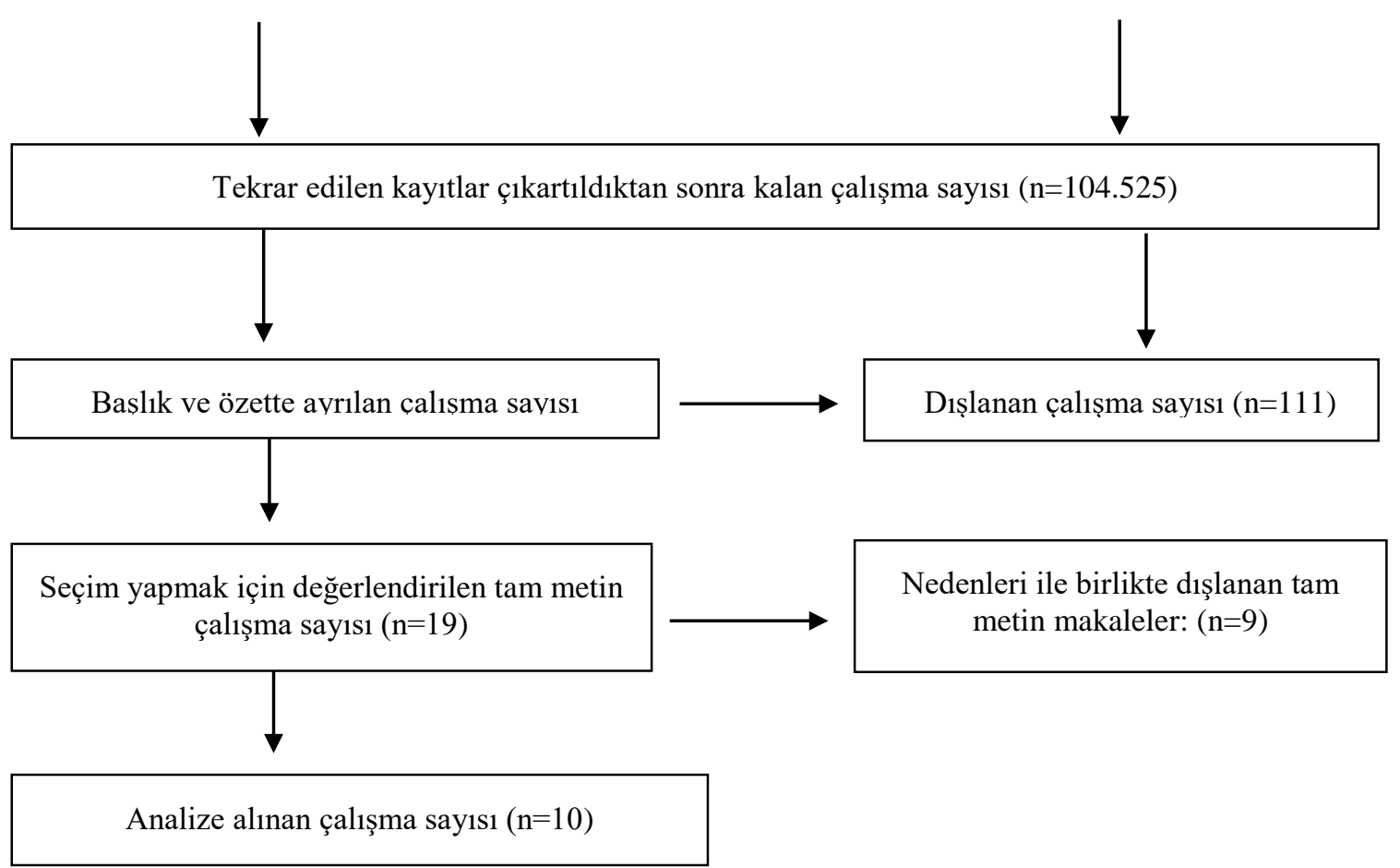

Şekil 1: Çalışmaların seçimi ve alınma süreci

\section{Çalışmalarda Uygulanan Öğretim Yöntemleri ve Etkinliği}

Araştırma kapsamında değerlendirmeye alınan çalışmalarda, sekiz ayrı öğretim yöntemi uygulandığı görülmektedir. Bu öğretim yöntemlerden dördü farklı başlıklar altında incelenmiş (Standart hasta kullanımı, similatör kullanımı, kriz kaynak yönetimi eğitiminin kullanılması, pozitif psikoterapinin kullanılması), dört tanesi ise teknolojinin kullanılması başlığı altında (akıllı telefonun kullanılması, çevrimiçi eğitim programı, alana özgü elektronik öğrenme programı, tıbbi içerikli film izletilmesi) ele alınmıştır.

\section{Standart Hasta Kullanımı}

Hemşirelik eğitiminde öğrenci sayısının artması ile birlikte, klinik uygulamalarda öğrencinin her şeyi görüp, uygulayıp öğrenme şansı giderek azalmaktadır. Bu nedenle farklı yöntemler kullanılarak öğrenmenin sağlanması hedeflenmektedir. Bu yöntemlerden biri; hasta gibi rol yapan bireylerin bu amaçla kullanılmasıdır. Bu yönteme "standart hasta kullanılması" denilmektedir. Başak ve ark. (2019) yapmış olduğu çalışmada; deney grubuna standart hastadan faydalanılarak hijyen becerileri eğitimi verilmiş ardından konuya ilişkin beceriler değerlendirilmiştir. Çalışma sonunda, eğitimde standart hasta kullanımının, öğrencinin özgüvenini olumlu yönde etkilediği belirtilmiştir. 
Tablo 2. Yayınların Metadolojik Olarak Değerlendirilmesi (N=10) (The Joanna Briggs, 2017)

\section{CONSORT DEĞERLENDİRME KRITERLERİ}

\section{YAYIN (Yazar, yl)}

\begin{tabular}{|c|c|c|c|c|c|c|c|c|}
\hline 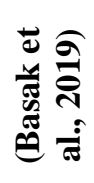 & 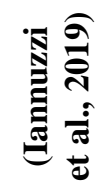 & \& & 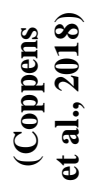 & 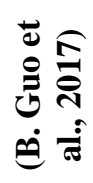 & 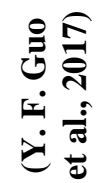 & 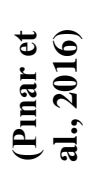 & 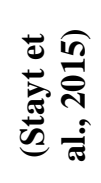 & 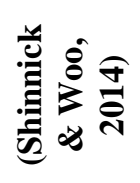 \\
\hline
\end{tabular}

Katılımcıları gruplarına atamak için gerçek randomizasyon kullanıldı

$\mathrm{m} 1$ ?

Gruplardaki atamalar gizlendi mi?

Gruplar başlangıçta benzer miydi?

$+\quad+$

$++$

$\begin{array}{llllllllll}? & -- & + & ? & -- & -- & ? & + & + & -- \\ + & + & + & + & + & + & + & + & + & + \\ + & -- & -- & -- & -- & -- & ? & ? & + & -- \\ ? & -- & -- & -- & -- & -- & ? & - & -- & -- \\ ? & -- & -- & -- & -- & -- & ? & ? & -- & -- \\ + & + & + & + & + & + & + & + & + & +\end{array}$

Uygulayıcılara körleme uygulandı $\mathrm{m}$ ?

Sonuçları değerlendirenlere körleme uygulandı mı?

Müdahale grubuna uygulanan girişim dışında tüm gruplara aynı

$+\quad+\quad+$

müdahaleler uyguland $1 \mathrm{mi}$ ?

İzlem tamamlandı $\mathrm{m} 1$, gruplar arasındaki farkların analizi yapıldı $\mathrm{m}$ ?

Katılımcıların analizleri kendi gruplarında yapıldı mı?

Gruplara aynı ölçümler yapıldı mı?

Sonuçlar güvenilir bir şekilde ölçüldü mü?

Uygun istatistiksel analizler yapıldı $\mathrm{m}$ ?

Deneme tasarımı uygun mu ve standart RCT tasarımından (bireysel

randomizasyon, paralel gruplar) yapilan herhangi bir sapma,

çalışmanın yürütülmesi ve analizinde dikkate alındı mı?

\begin{tabular}{|c|c|c|c|c|c|c|c|c|c|c|}
\hline Var olan kriter sayısı & 9 & 8 & 9 & 8 & 8 & 8 & 8 & 9 & 11 & 8 \\
\hline Bulunmayan kriter sayısı & 4 & 4 & 3 & 3 & 4 & 4 & - & 1 & 2 & 4 \\
\hline Daha fazla bilgiye ihtiyaç olan kriter sayısı & -- & 1 & 1 & 2 & 1 & 1 & 5 & 2 & -- & 1 \\
\hline
\end{tabular}

+: Var, --: Yok, ?: Daha fazla bilgiye ihtiyaç 
Tablo 3. Dahil Edilen Çalışmalarda Uygulanan Girişimler ve Değerlendirmede Kullanılan Yeterlik Ölçüm Araçları

\begin{tabular}{|c|c|c|c|c|}
\hline $\begin{array}{l}\text { YAYIN } \\
\text { (Yazar, yıl) }\end{array}$ & $\begin{array}{l}\text { GÍRİŞIM } \\
\text { (DENEY) }\end{array}$ & $\begin{array}{l}\text { GÍRIŞíM } \\
\text { (KONTROL) }\end{array}$ & ÖLÇME ARACI & $\begin{array}{l}\text { ÖRNEKLEM } \\
\text { (DENEY / } \\
\text { KONTROL) }\end{array}$ \\
\hline (Basak et al., 2019) & $\begin{array}{l}\text { Standart hasta } \\
\text { kullanılarak } \\
\text { eğitim verilmiş }\end{array}$ & $\begin{array}{l}\text { Maket kullanılarak } \\
\text { eğitim verilmiş }\end{array}$ & $\begin{array}{l}\text { Öğrenci memnuniyet ve öz- } \\
\text { güven ölçeği }\end{array}$ & $40 / 40$ \\
\hline (Iannuzzi et al.,2019) & $\begin{array}{l}\text { Çevrimiçi } \\
\text { eğitim } \\
\text { uygulanmış }\end{array}$ & $\begin{array}{l}\text { Didaktik eğitim } \\
\text { uygulanmış }\end{array}$ & $\begin{array}{l}\text { Aile Hekimliği Uygulayıcısı } \\
\text { Otizm Öz-yeterlik Ölçeği }\end{array}$ & $8 / 8$ \\
\hline (Kim \& Suh, 2018) & $\begin{array}{l}\text { Akıllı telefonlar } \\
\text { aracılığı ile } \\
\text { eğitim modülü } \\
\text { kullanılmış }\end{array}$ & $\begin{array}{l}\text { Eğitim videoları } \\
\text { izletilmiş }\end{array}$ & $\begin{array}{l}\text { Klinik hemşirelik becerileri öz- } \\
\text { yeterlik formu }\end{array}$ & $34 / 36$ \\
\hline (Coppens et al., 2018) & $\begin{array}{l}\text { Kriz kaynak } \\
\text { yönetimi eğitimi } \\
\text { verilmiş }\end{array}$ & $\begin{array}{l}\text { Simülasyonla eğitim } \\
\text { verilmiş }\end{array}$ & Genel öz-yeterlik ölçeği & $60 / 56$ \\
\hline (B. Guo et al., 2017) & $\begin{array}{l}\text { Tıbbi içerikli } \\
\text { belgesel } \\
\text { izletilmiş }\end{array}$ & $\begin{array}{l}\text { Normal müfredat } \\
\text { uygulanmış }\end{array}$ & Profesyonel öz-yeterlik formu & $122 / 115$ \\
\hline (Y. F. Guo et al., 2017) & $\begin{array}{l}\text { Pozitif } \\
\text { psikoterapi } \\
\text { uygulanmış }\end{array}$ & $\begin{array}{l}\text { Normal müfredat } \\
\text { uygulanmış }\end{array}$ & Genel öz-yeterlik ölçeği & $42 / 43$ \\
\hline (Pinar et al., 2016) & $\begin{array}{l}\text { Simülatörlerle } \\
\text { video tabanlı } \\
\text { eğitim verilmiş }\end{array}$ & $\begin{array}{l}\text { Geleneksel eğitim } \\
\text { verilmiş }\end{array}$ & $\begin{array}{l}\text { OSCE (Objective Structured } \\
\text { Clinical Examination) }\end{array}$ & $23 / 23$ \\
\hline (Stayt et al., 2015) & $\begin{array}{l}\text { Similatörlerle } \\
\text { eğitim verilmiş }\end{array}$ & $\begin{array}{l}\text { Geleneksel eğitim } \\
\text { verilmiş }\end{array}$ & $\begin{array}{l}\text { Öz-yeterlik ölçeği } \\
\text { OSCE }\end{array}$ & $50 / 48$ \\
\hline (Shinnick \& Woo, 2014) & $\begin{array}{l}\text { Simülatörlerle } \\
\text { eğitim verilmiş }\end{array}$ & $\begin{array}{l}\text { Klasik eğitim } \\
\text { verilmiş }\end{array}$ & $\begin{array}{l}\text { Kalp yetmezliğinin yönetiminde } \\
\text { öz-yeterlik ölçeği }\end{array}$ & $82 / 79$ \\
\hline (McMullan et al., 2011) & $\begin{array}{l}\text { İlaç hazırlama } \\
\text { eğitimi paket } \\
\text { programı } \\
\text { kullanılmış }\end{array}$ & $\begin{array}{l}\text { Geleneksel eğitim } \\
\text { verilmiş }\end{array}$ & İlaç hazırlama öz-yeterlik ölçeği & $92 / 45$ \\
\hline
\end{tabular}

\section{Simülatör Kullanımı}

Hemşirelik eğitiminde simülatör kullanımı, her öğrenciye eşit öğrenme firsatı tanımaktadır. Simülasyon, yetişkin öğrenme ilkeleri aktif olarak kullanıldığı zaman farklı öğrenme stillerinin gelişimine firsat tanıyan bir yöntemdir. Kimhi ve ark. (2016) yapmış olduğu çalışmada, simülatörler üzerinde ilaç uygulama, nazogastrik sonda uygulama, foley katater yerleştirme ve iletişim becerileri öğrencilere uygulamalı olarak göstermiş ve bu öğretim yöntemlerinin aynısı ertesi gün simülatörler üzerinde becerileri uygulamaları istenerek değerlendirilmiştir (Kimhi et al., 2016). Shinnick ve Woo (2014)'nun çalışmasında ise simülatörler kullanılarak kalp yetmezliği anlatılmış, ardından kalp yetmezliğine yönelik üç ayrı vaka senaryosu hazırlanmıştır. Öğrencilerin simülatörlere uyguladıkları hemşirelik öğretim yöntemlerinin hemşirelik sürecine uygunluğu değerlendirilmiştir (Shinnick \& Woo, 2014). Simülatörlerle verilen eğitim ve pozitif psikoterapinin; öğrencilerin genel öz yeterliklerini olumlu yönde etkilediği görülmüştür. (Coppens et al., 2018; Y. F. Guo et al., 2017). Smilatörlerin video tabanlı uygulandığ da görülmektedir. Video tabanlı uygulamada deney grubundaki öğrencilere 2 saat similatörler eşliğinde yenidoğanın bakımına yönelik eğitim verilmiş ve geleneksel eğitim verilen kontrol grubu ile karşılaştırılmıştır. Sonuçta da öğrencilerin alana yönelik yeterliklerini değerlendirmek için OSCE formu kullanıldığı belirtilmiştir. Çalışmada hemşirelik eğitiminde simülatör kullanımı öğrencilerin yenidoğan konusundaki beceri yeterliklerine olumlu ve önemli bir katkı sunduğu görülmüştür (Pınar et al., 2016)

Similatörlerin kullanıldığı diğer bir çalışmada ise hastanede yatan riskli durumdaki hastayı tanımak ve durumu yönetmekte simülasyonun etkisine değerlendirilen çalışmadır. Çalışmada, eğitim verilen grupların özyeterliklerinin ve OSCE ile alana yönelik yeterliklerinin değerlendirildiği görülmektedir. Çalışmada, similatör ile eğitim verilen gurup ve kontrol gurubu arasında öz-yeterlik ve OSCE puanlarında fark olmadığı, fakat similatör 
eğitimi alan öğrencilerde klinik uygulamaya ilişkin daha iyi performans gösterdikleri belirtilmiştir (Stayt et al., 2015).

\section{Kriz Kaynak Yönetimi Eğitiminin Kullanılması}

Kriz, acil bir durumdur ve bu durumda var olan imkânların kullanılması ile soruna çözüm üretilebilme süreci de kriz yönetimi olarak ifade edilmektedir (Tekin, 2015). Hemşirelik eğitimlerinde, hasta ile ilgili oluşturulan acil durum senaryoları aracılığı ile bu acil durumların en doğru ve hızlı şekilde çözülmesi hedeflenmektedir. Coppens ve ark (2017)'nın çalışmasında, hastaya acil müdahale uygulanması gereken durum temalı senaryo kriz kaynak yönetimi eğitimi başlı̆g altında simülatör kullanılarak verilmiştir ve bu yöntemin öğrencilere olumlu katkı sunduğu belirtilmiştir (Coppens et al., 2018).

\section{Pozitif Psikoterapinin Uygulanması}

Pozitif psikoterapide amaç insanın farkı bakış açıları geliştirmesinin sağlanmasıdır. Gou ve ark. (2017)'nın çalışmasında, öğrencilere üç ayrı oturum halinde pozitif psikoterapi uygulanmış, bu uygulamanın öğrencilerin öz yeterliklerini olumlu yönde etkilediği belirtilmiştir (Y. F. Guo et al., 2017).

\section{Eğitimde Teknolojinin Kullanımı}

Teknoloji, eğitimde farklı alanlarda ve farklı şekillerde kullanılmaktadır, bunlar ayrı başlıklarda ele alınmıştır:

a. Akıllı telefonda eğitim modülünün kullanılması: Eğitimde teknoloji temelli eğitim yöntemlerinden biri akıllı telefon uygulamalarının kullanılmasıdır. Kim ve Suh (2018)'un çalışmasında, dört hemşirelik becerisi (yaşam bulgularının alınması, intravenöz enjeksiyon, endotrakeal aspirasyon ve gastrik lavaj) ele alınmış, öğrencilerin dikkat, ilgi, kendine güven ve memnuniyet çıktıları değerlendirilmiştir. Bu çalışmada uygulama ve değerlendirme aşamaları akademisyenler tarafından hemşirelik sürecine entegre edilerek oluşturulmuş ve çalışma sonucunda akıllı telefon uygulaması ile yürütülen eğitimin klinik hemşirelik becerileri yeterliliğini artırdığı belirtilmiştir.

b. Çevrim içi eğitim programının kullanılması: Oluşturulan bir eğitim programının bilgisayardan faydalanılarak uygulanması esasına dayanmaktadır. Pek çok alanda uygulanan bu yöntem Lannuzzi ve ark. (2019)' nın çalışmasında otizimli bireylerle ilgilenen hemşirelik öğrencilerinin tutum gelişimi amaciyla kullanılmış ve beklenen çıktılar didaktik eğitimle karşılaştırılmıştır. Bu çalışmada, eğitim sonrasında öğrencilerin otizmli bireye ve aileye karşı olumlu tutum geliştirdikleri belirtilmiştir.

c. İlaç hazırlama paket programının kullanımı: McMullan ve ark. (2011)'nın çalışmasında, elektronik öğrenme programı oluşturulmuş, öğrencilerin kendi kendine ilaç hesaplamasını öğrenmeleri hedeflenmiştir. Programda; oral ilaçlar, sıvı ilaçlar/enjeksiyonlar, farklı birimlerle ilaç hesaplamaları, karmaşık ilaç yüzdelerinin hesaplanması, dakikada/ saatte gönderilmesi gereken sıvı miktarı başlıklarına yer verilmiştir. Kullanılan paket programın, ilaç hazırlama yeterliliğini olumlu etkilediği belirtilmiştir.

d. Tıbbi içerikli belgeselin izletilmesi: Film izletimi içerik olarak bakıldığında eğitim aracı olarak da kullanılanılmıştır. Guo ve ark. (2017)'nın çalışmasında tıbbi belgesel olarak Pekin' de televizyonlarda seri olarak gösterilen bir belgesel (Life Ties) tercih edilmiştir. Haftada bir gün ve bir saat süre ile gösterilen belgeselde iki ana tema yer almıştır. Temalardan ilki sağlık personelinde özveri, ikincisi ise sağlık personelinin yaşadığı zorluklara ilişkin konuları işlemiştir. Çalışmada, öğrencilerin mesleki yeterlik ve profesyonel kimlik gelişimlerine etkisi değerlendirilmiş, film izletiminin öğrencinin profesyonel öz yeterliliğine olumlu katk1 sunduğu ifade edilmiştir

\section{Çalışmalarda Kullanılan Ölçme Araçları}

Burada yer alan çalışmalarda, toplam 8 ayrı ölçme aracı kullanıldığı görülmektedir, bu ölçme araçları aşağıda sırasıyla verilmiştir.

1. Öğrenci Memnuniyeti ve Öğrenmede Kendine Güven Ölçeği (Students’ Satisfaction And SelfConfidence Scale) 
“Öğrenci memnuniyeti ve öğrenmede kendine güven ölçeği” Jeffries ve Rizzolo (2006) tarafından geliştirilmiştir. Orijinal hali 13 maddeden oluşan ölçekte 5 madde simülasyonun etkinliğini, 8 madde ise öğrenci memnuniyeti ve öğrencinin kendine güvenini ölçmektedir. Ölçeğin Türkçe versiyonu 12 madde olarak kullanılmaktadır. Türkçe geçerlik güvenirliği yapılan ölçekteki alt boyutlar; "mevcut öğrenme ile tatmin" ve “öğrenmede kendine güven” dir. Türkçe ölçeğin Cronbach alfa değeri 0,90’dır. Beşli likert tipi ölçekte yüksek puan yüksek özgüven ve memnuniyeti göstermektedir (Basak et al., 2019; Unver et al., 2017).

\section{Genel Öz Yeterlilik Ölçeği (Generalized Perceived Self-Efficacy Scale)}

Bandura tarafından tanımlanmış olan Genel öz yeterlik ölçeği (Bandura, 1977) Scholz ve Schwarzer tarafından 20 madde olarak geliştirilmiştir (Schwarzer \& Schroder, 1997). "Genel öz yeterlik ölçeği” daha sonra pek çok dile çevrilmiş, tüm dillerde 10 madde olarak kullanılmaya başlanmıştır (Zhang et al., 2015). Türkçe geçerlik güvenirliği Erci (2006) tarafından yapılan ölçeğin Cronbach alfa değeri 0,89' dur. Dörtlü likert tipi olan ölçekte puanlar; 10-40 arasında değişmekte ve ölçekten alınan yüksek puan yüksek öz yeterliliği ifade etmektedir (Erci, 2006).

3. Hemşirelik Öğrencilerinde Profesyonel Öz Yeterlik Formu (Professional Self-efficacy Guestionnaire for Nursing Students) "Hemşirelik öğrencilerinde profesyonel öz yeterlik ölçeği”; 27 maddeden oluşan, beşli likert tipi bir ölçektir. Hao Yufang tarafından 2011' de geliştirilmiştir. Form, mesleki yeterlik ve profesyonel kimlik alt başlıklarında değerlendirmeyi sağlamaktadır. Mesleki yeterlik alt başlığında; mesleki tutum ve inançlar, problem çözme, profesyonel olarak bilgi toplama ve planlama kapasitesi, mesleki biliş, mesleki değerler, profesyonel tercih yer almaktadır. Cronbach alfa değeri 0,84' tür. Toplam puan 27-135 arasında değişmekte ve ölçekten alınan yüksek puan yüksek yeterliği ifade etmektedir (B. Guo et al., 2017).

4. Klinik Hemşirelik Becerileri Öz Yeterlik Formu (Self Efficacy of Nursing Practice) "Klinik hemşirelik becerileri öz yeterlik formu" öğrencilerin klinik becerilerinin değerlendirilmesi amacıyla hazırlanmıştır. Dört uygulama temel alınmış ve bu alanlarda toplam 129 başlıktan oluşan ölçek geliştirilmiştir. Ölçekteki dört ana başlık; hayati bulguların alınması, intravenöz enjeksiyon, gastrik gavaj ve endotrakeal aspirasyondur. Ölçekte, bu uygulamalar için ön hazırlık ve malzemelerin hazırlanması ve becerilerin doğru sıralanması yer almaktadır. Değerlendirme ise; iyi, orta, kötü şeklinde yapılmaktadır. Cronbach alfa değeri 0,90'dır. Ölçekten alınan yüksek puan yüksek yeterliliği ifade etmektedir (Kim, 2018).

\section{Alana Yönelik Yeterliklerin Değerlendirildiği Ölçekler}

Alana yönelik olarak farklı yeterliklerin değerlendirildiği görülmektedir. Bunlar aşağıda dört ayrı başlıkta toplanmıştır:

\section{a. OSCE (Objective Structured Clinical Examination/ Objektif yapılandırılmış klinik değerlendirme formu)}

"OSCE" olarak adlandırılan form, bir alana yönelik objektif olarak düzenlenmiş, yapılandırılmış bir değerlendirme formdur. Bu form her alan için kendine özgü beklentileri doğrultusunda şekillendirilebilmektedir. Harden ve Gleeson tarafindan (1979) tanımlanmış olan form ilk olarak tıp eğitimiyle kullanılmaya başlanmıştır. Hem klinik uygulamalara hem teorik bilgilere hem de sözlü sınavlara uyarlanabilir olması bir avantajdır. Formun oluşturulması, uygulama alanlarının düzenlenmesi, değerlendiricinin konuya hakimiyetinin önemli olduğu bir uygulamadir (Zartman et al., 2002).

\section{b. Otizm Öz Yeterlik Ölçeği (Family Nurse Practitioner Autism Self-Efficacy Scale (FNPASE)}

"Otizm öz yeterlik ölçeği” otizmli bireylerin hizmet sağlayıcılarının bu alanda yeterliklerini ölçmeyi hedefleyen bir ölçektir. Mazurek ve ark (2016) tarafından "Birinci basamakta otizm öz yeterliliği ölçeği” olarak geliştirilmiştir. Orijinal ölçek 57 maddeden oluşmaktadır. Altılı likert tipi bir ölçektir ve. İç tutarlılığı yüksektir (0,88-0,97) (Mazurek et al., 2017). Çalışmada kullanılan ölçme aracı Mazurek ve ark (2016)'nın 57 maddelik ölçeği örnek alınarak oluşturulmuş; 27 maddelik, altılı likert tipi bir ölçektir. Toplam puan 27-108 arasında değişmekte, yüksek puan yüksek yeterliliği göstermektedir (Iannuzzi et al., 2019) 


\section{c. İlaç Hazırlama Öz Yeterlik Ölçeği (Drug Calculations Self-Efficacy Scale)}

Hemşirelik öğrencilerinin ilaç hazırlamaya yönelik becerilerinin ve yeterliklerinin değerlendirilmesi amacıyla geliştirilen "İlaç hazırlama öz yeterlik ölçeği” toplam altı sorudan oluşan, 10'lu likert tipi bir ölçektir. Ölçeğin, pilot çalışmada iç tutarlılığ 0,90 olarak bildirilmiştir. Toplam puan 0-60 arasında değişmekte, yüksek puan yüksek yeterliliği göstermektedir (McMullan et al., 2011)

\section{d. Kalp Yetmezliğinin Yönetiminde Öz Yeterlik Ölçeği (Self-Efficacy in the Management of Heart Failure)}

“Kalp yetmezliğinin yönetiminde öz yeterlik ölçeği”, Ravert tarafindan 2004 yılında geliştirilmiştir. Orijinal ölçek 24 sorudan oluşan likert tipi bir ölçektir. İki ayrı ölçekten faydalanarak "Hemşirelik Becerilerinin Değerlendirilmesi için Öz Yeterlilik" adıyla kullanmıştır (McArthur Ravert, 2004). Çalışmada kullanılan versiyonu, kalp yetmezliğinin yönetilmesi, doktor orderlarının da uygulama önceliğine karar verilmesi ve sıvı uygulamasının yönetimi başlıklarını içermektedir. Ölçeğin güvenirliği 0,90'dan fazladır ve ölçekten alınan yüksek puan yüksek yeterliliği göstermektedir (Shinnick \& Woo, 2014).

\section{TARTIŞMA}

Yeterlik, hemşirelik öğrencileri için önemlidir ve geliştirilmesi gerektiği vurgulanmaktadır. Yapılan çalışmalar, hemşirelerde yeterliliği geliştirmek için kullanılan pek çok yöntemin bulunduğunu ve farklı ölçme yöntemleri ile farklı yeterlik başlıklarında değerlendirmelerin yapıldığını göstermektedir (Açıksöz et al., 2016; B. Guo et al., 2017; Shinnick \& Woo, 2014; Zhang et al., 2015). Bunlar aşağıda; eğitimde similatör ve standart hasta kullanımı, kriz kaynak yönetimi eğitiminin kullanımı, pozitif psikoterapinin kullanımı ve ölçme araçları ile değerlendirilmesi alanında sırasıyla tartışılmıştır:

Hemşirelik eğitiminin temel bileşenlerinden birini klinik uygulamalar oluşturmakta ve aslında en büyük sorun da bu alanda karşımıza çıkmaktadır. Bu nedenle eğitimde simülasyonların desteğinin alınması önerilmektedir (Amado Martins et al., 2018). Similatörler, gerçek dünyayı taklit etmeyi sağlayan teknoloji temelli eğitim araçları olarak tanımlanmaktadırlar. Düşük teknolojik özellikte, bilgisayar destekli, kompleks fonksiyonlar içerebilen bütünleşik özellikler taşıyan simülatör modelleri bulunmaktadır. Bunların yanında gerçek hasta simülasyonu denilen hasta rolü yapan gerçek bireylerin görev aldığı simülasyonlar da eğitimde sıklıkla kullanılmaktadır (Durmaz Edeer \& Dicle, 2015). Hemşirelik eğitiminde simülatör kullanımı ve standart hasta kullanımının kendi içinde avantaj ve dezavantajlı durumları olduğu bildirilmektedir. (Andrea \& Kotowski, 2017; Holland et al., 2017; Uslu \& Yavuz van Gierberger, 2019). Özellikle simülatörün kendisine yüklenen verileri kullanması ve duygularının olmaması bir dezavantaj olabilirken; iyi rol yapamayan, eğitim almamış olan, ya da kendisinde var olan sağlık sorunları sebebiyle duygusal olarak farklı tepkiler gösteren canlı hasta simülatörleri de istendik sonuca ulaşmayı etkilemektedir. Bunların aksine; eğitimde standart hasta kullanımı öğrencileri iletişim becerilerinin gelişmesini olumlu yönde etkileyebilmektedir. Hasta bireye ilk kez dokunmak öğrenciyi ilk uygulamada tedirgin edebilecekken bunu klinik uygulama öncesi hasta rolü yapan bir bireye dokunarak gerçekleştirmesi, öğrencinin motivasyon, cesaret ve öz güvenini artırabilmektedir (Uslu \& Yavuz van Gierberger, 2019). Hasta rolünde sinıftaki bir öğrencinin yer alması ise öğrencinin kendisinin farklı yönlerini görmesini desteklemesi adına önemlidir. Ayrıca standart hasta kullanımının, simülatör kullanımına göre maliyet etkin bir yöntem olduğu bildirilmektedir (Andrea \& Kotowski, 2017). Similatör kullanımı öğrenmeyi desteklerken öğrencinin kaygısını azaltarak öğrenmenin etkinliğini artırdığı, geleneksel eğitim verilen gurupla simülatör kullanılan gurubun kaygı düzeyleri arasındaki farkın da anlamlı olduğu $(\mathrm{p}<0,005)$ belirtilmektedir (Holland et al., 2017). Alana yönelik hazırlanmış vaka örneklerinin simülatör kullanarak uygulandığı eğitimlerin ise hemşirelerin kendilerini daha yeterli hissetmesinde etkili olduğu açıklanmıştır (Jonson et al., 2017). Simülatörlerin öğrenmeyi ve kaygının azaltılmasını desteklediği ve zevkli hale getirdiği kabul edilmesi gereken bir gerçektir.

Öğrenmeyi desteklemek amacıyla farklı eğitim programları da uygulanabilmektedir. Bunlardan biri kriz kaynak yönetimi eğitimidir. Bu eğitim, havacılık sektöründe kullanıldığında ölüm oranının \%70 oranında azaldığı görülmüş ve sağlık eğitiminde de kullanılmasının uygun olacağı düşünülerek hemşirelik eğitimine uyarlandığı 
belirtilmiştir (Carne et al., 2012). Kriz kaynak yönetimi eğitiminde; ekip çalışmasını etkin hale getiren becerilerin ele alındığı görülmektedir. Burada teknik beceriler olabileceği gibi teknik olmayan becerilere de yer verilmektedir. Hemşirenin liderlik rollerinden biri olarak hasta ile ilgili olan acil duruma liderlik edebilmesi, özellikle bu durumda iletişimi doğru kullanarak adımların doğru atılmasını sağlaması beklenmektedir. Hemşirenin krizi iyi yönetmesi, iletişimi doğru kullanması hastanın hayatının kurtulmasında önemli bir yere sahiptir (Edmonson et al., 2016). Bu nedenle öğrenci hemşirelere, krizi doğru yönetmeyi hedef alan eğitimlerin verilmesinin uygun olacağı bu sayede lider rolüne yakınlaştırılabileceği ifade edilebilir.

Verilen eğitimin başarısında eğitim verilen grubun duygu ve düşünceleri önemli bir etkiye sahiptir. Pozitif psikoterapi; bireylerde olumlu duygu, düşünce ve davranışları ortaya çıkarmayı hedefler ve pozitif davranışları ortaya çıkartacak pozitif aktiviteler üretilmesini sağlar. Böylece bireylerin daha güçlü olmalarına ve kendilerini daha iyi hissetmelerine yardımcı olur (Y. F. Guo et al., 2017) Buna göre kişinin olumlu duyguları, düşünceleri ve davranışları sistematik ve etkili bir biçimde ortaya çıkabilir. Bireyin olumlu sonuçlar elde etmesi ise onun kendini iyi, güçlü ve yeterli hissetmesini destekleyen önemli bir etkendir. Pozitif psikoterapi özellikle çocuk ve gençlerde onları sosyal hayatta desteklemek için önerilen bir yöntemdir (Layous et al., 2011). Bu nedenle genç yaş grubunda yer alan hemşirelik öğrencisinin kendini yeterli hissetmesinde pozitif psikoterapi eğitimiyle desteklenmesi uygun olabilir.

Gelişen teknoloji ile birlikte eğitimde teknoloji kullanımı, hem öğrenmeyi kolaylaştıran hem de eğlenceli hale getiren bir etkiye sahiptir (Erdoğan \& Bulut, 2017). Bunlardan biri de filmlerin-videoların öğrencilere izletilmesidir. Bu uygulamanın; öğrenci için tercih edilen, öğretim elemanı için de kolaylaştıran bir uygulama olduğu açıklanmaktadır (Akın Korhan et al., 2016). Özellikle Z kuşağı eğitiminde teknolojiyi kullanarak öğrencilerin dikkatini çeken, farkındalıklarını artıran yöntemler önerilmektedir. Çünkü bu grup teknolojiyle daha iç içe yaşamaktadır (Çonoğlu et al., 2020). Eğitim amaçlı belgesellerin izlettirilmesi (B. Guo et al., 2017), akıllı telefonlar aracılığı ile videolar kullanılarak görselin zenginleştirilmesi hemşirelik öğrencilerinde özellikle duyuşsal zeka ve iletişim becerilerine olumlu katkı sunmaktadır (Choi et al., 2015). İzlenilen filmle birlikte öğrenciye, konuya yönelik yazılı metnin sunulmasının öğrenmeyi ve konunun akılda kalmasını desteklediği de belirtilmektedir (B. Guo et al., 2017). Lee ve ark.'nın (2018) yaptığı sistematik derlemede; öğrenciler teknolojinin kullanıldığı, görselle zenginleştirilmiş öğretim yöntemlerini geleneksel yöntemlerden daha çok beğendiklerini açıklamaktadır (Lee et al., 2018). Ayrıca öğrencinin daha güvenli bir alanda, seçilerek sunulmuş olan video- belgesel vs gibi filmler izletilmesinin öğrenci ya da öğretim elemanını hukuki olarak da zorda bırakmadan öğrenmeyi destekleyebilmektedir (Ayhan et al., 2018). Teknolojik yöntemlerin kullanıldığı eğitim modellerinde de geleneksel yöntemde olduğu gibi grubun özelliklerine, eğitim durumuna, akademik seviyesine ve grubun sayısına göre doğru tercih edilmesinin başarıda önemli olduğu açıklanmaktadır (Bianchi et al., 2020). Eğitim amaçlı kullanılacak video/belgesel/film tercihinin profesyonelce yapılmasının önemli olduğu, doğru şartlar oluşturularak teknolojinin hemşirelik eğitimine entegre edilmesinin uygun bir tercih olabileceği söylenebilir.

Öğrenciye verilen eğitimin hangi araç ya da yöntemle verilirse verilsin ölçülmesi ve değerlendirilmesi gerekmektedir. Ölçmek, sayısal bir sonuç elde etmek, değerlendirmek ise bu sonucu anlamlandırmak olarak ifade edilmektedir. Ölçme işlemi sadece öğrencilerin akademik başarısını değerlendirmek amacıyla değil aynı zamanda sosyal ve psikolojik durumu, genel durumu, olayların ilerleyişi gibi pek çok başlıkta değerlendirme yapmayı mümkün kılan nitelikte olmaktadır. Alana özel becerileri sıralamayı, sınıflandırmayı, derecelendirmeyi sağlayan, ölçme araçlarıdır. Özellikle uygulamalı bir alanda ölçme işleminin yapılması, değerlendirmenin doğruluk payını artırmakta, yanlışı, doğruyu, eksiği görebilmeyi sağlamaktadır (Karakoç \& Dönmez, 2014).

Genel olarak bakıldığında hem öğrenci hem de öğretim elemanlarının kullanılan öğretim yöntemlerinden memnun olmadığı belirtilmektedir (Rowbotham \& Owen, 2015; Vizeshfar \& Torabizadeh, 2018). Her iki grubun da hoşnut olmadığı bir uygulama ile olumlu sonuç elde etmek de zor olacaktır. Özellikle öğrencilerin tercih ettiği öğretim yöntemi kullanıldığında, yöntemin öğrenci başarısına \%65 oranında katkı sunduğu açıklanmaktadır (Vizeshfar \& Torabizadeh, 2018). Bu nedenle kullanılan yöntem hakkında öğrencinin memnuniyetinin bir ölçme aracı ile değerlendirilmesi önemlidir. Bu sayede yeni müfredatın oluşturulmasına ve eğitim programlarının düzenlenmesine katk1 sunulabilecektir. 
George ve ark.'nın (2017) yürüttüğü çalışmada, öğrencilerin klinik eğitim öncesi ve sonrası yeterliklerine bakıldığında klinik eğitimden sonra yeterliklerinin arttığı saptanmıştır. Bu da eğitimin sadece teorik düzeyde yürütülmesinin yetersiz olduğunu göstermiştir. Eğitimde similatör kullanımı sonrası öğrencinin artan öz-yeterlik puanı da teorik eğitimin uygulama ile desteklendiği durumlarda öğrencinin kendini daha yeterli hissettiği sonucuna ulaştırmıştır (Holland et al., 2017). Başka bir çalışmada, afet sonrası yapılması gereken uygulamalar hakkında verilen eğitim sonrası öğrencilerde $35.7 \pm 5.06$ olan yeterlik puanlarının $39.8 \pm 4.1$ ' e yükseldiği ve farkın da anlamlı olduğu görülmüştür ( $<<0,05)$ (Jonson et al., 2017). Bu üç çalışmada (George et al., 2017; Holland et al., 2017; Jonson et al., 2017), öğrencinin uygulamasına firsat veren yöntemlerle eğitim verilmesi ve eğitimin ardından yeterliklerinin değerlendirilmesi gerektiği sonucuna ulaşılmıştır.

Hemşirelik eğitiminde kuramsal içeriğin uygulama ile birleştirilmesi gerekmektedir. Bu kapsamda öğrencilere "hemşire olmak" öğretilmeye çalışılmaktadır Teorik olarak bilgiler öğretilmekte, bu bilgiler sınavla sınanabilmektedir. Bu sınavların içerisinde uygulamalara ilişkin beceri yeterlikleri de yer almaktadır (Boztepe \& Terzioğlu, 2010). Bir literatür incelemesine göre, öğrencilerin değerlendirilmesinde gözlemle değerlendirme, öğrencinin yeterliğini kendi değerlendirmesi, her iki yöntemin birlikte kullanılması şeklinde uygulamaların bulunduğu açıklanmaktadır (kaynak). Daha çok tercih edilen ise öğrencilerin performansı gözlenerek klinik beceri listeleri ile değerlendirmeleri yönündedir. Hemşirelikteki klinik becerilerin tamamına bir tek değerlendirme aracı oluşturmanın zor olduğu belirtilmiş, alana, değerlendirilmek istenen konuya yönelik araçların geliştirilmesinin ve kullanımının doğru olacağı açıklanmıştır (Reljic et al., 2017). Bu kapsamda hemşireliğe yönelik istendik profesyonel davranışların, klinik hemşirelik becerilerinin, ilaç hazırlama becerisinin, kalp yetmezliğine yönelik yapılması gereken uygulamaların alana özgü hazırlanmış olan ölçme araçları ile değerlendirilmesi gerekmektedir. Değerlendirmelerden elde edilen sonuçlar, öğrencideki davranış değişikliği, beceriye ilişkin eksikleri, hataları gözlemlemeye, öğrencinin daha objektif olarak değerlendirilmesine ve eğitimin etkinliğinin yeterli olup olmadığına karar vermeye katk1 sunacaktır.

Hemşirelik eğitiminde pek çok hastalık ayrıntılı olarak işlenmektedir. Ancak bazı özel durumlarda, nadir görülen hastalıklarda veya iletişim ile ilgili engeli bulunan bireylerle iletişimde yeterli olmakta sorun yaşanabilmektedir. Bunlardan biri de otizmli bireye yaklaşım konusudur. Otizmli bireylerle yapılan çalışmaların incelendiği bir derlemede, otizmli bireylerle iletişim için ayrıca alternatif ve destekleyici iletişim sistemlerinin öğrenilmesi ve uygulanması gerektiği belirtilmiştir (Karababa \& DİLmaÇ, 2015). Hemşirenin ise temel sağlık hizmetlerinin her aşamasında yer alan bir sağlik profesyoneli olarak otizmli birey ve ailenin eğitim, takip ve bakımını üstlenmesi gerekmektedir. Özellikle koruyucu ve rehabilite edici sağlık hizmetlerinde bu hasta grubu ve ailesinin hemşireye ihtiyacı kaçınılmazdır (Dur \& Mutlu, 2018). Bu kapsamda otizmli bireyle çalışan çalışan sağlık personellerine verilen eğitimin ardından otizmli bireylerle iletişim yeterliğinin bir ölçüm aracı kullanarak değerlendirilmesi önemlidir.

\section{SONUÇ ve ÖNERILER}

Öğrenciye verilen eğitimin ölçülmesi ve değerlendirilmesi önemlidir. Özellikle uygulamalı bir alanda ölçme işleminin yapılması değerlendirmenin doğruluk payını artıracak, yanlışı, doğruyu, eksiği görebilmeyi sağlayacaktır. Bunun sonucunda, kullanılan ölçme araçlarından Türkçe geçerlik güvenirlikleri yapılmamış olanlardan alana uygun olanının ülkemizde geçerlik güvenirlikleri yapılarak hemşirelik öğrencileri için kullanılması önerilebilir. Geçerlik güvenirliği yapılmış olan ölçme araçları ise farklı çalışmalarda değerlendirilebilir. Ayrıca öğrencilerin mesleki becerilerinin değerlendirildiği yeni ölçme araçları geliştirilebilir.

\section{Finansal destek}

Finansal destek alınmamıştır.

\section{Çıkar Çatışması}

Yazarların çıkar çatışması durumu yoktur. 


\section{Yazar Katkıları:}

Tasarım/Design: R.B.; Veri Toplama veya veri girişi yapma/Data Collection or Processing: R.B., H.D.; Analiz ve yorum/Analysis or Interpretation: R.B., H.D.; Literatür tarama/Literature Search: R.B., H.D.; Yazma/Writing: R.B., H.D.

\section{KAYNAKÇA}

Açıksöz, S., Uzun, Ş., \& Arslan, F. (2016). Investigation of the Relationship Between Self-Efficacy Perception and Anxiety and Stress Status in Clinical Practice in Nursing Students. Gülhane Medical Journal, 58, 129-135. https://doi.org/doi:10.5455

Akın Korhan, E., Tokem, Y., Uzelli Yılmaz, D., \& Dimelek, H. (2016). Hemşirelikte Psikomotor Beceri Eğitiminde Video Destekli Öğretim ve OSCE Uygulaması: Bir Deneyim Paylaşımı. İzmir Katip Çelebi Üniversitesi Sağllk Bilimleri Fakültesi Dergisi, 1(1), 35-37. https://doi.org/http://acikerisim.ikc.edu.tr:8080/xmlui/bitstream/handle/11469/554/6_1Hem\%c5\%9firelikte\%20Psikomot or\%20Beceri $\% 20 \mathrm{E} \%$ c4\%9fitiminde\%20Video\%20Destekli\%20\%c3\%96\%c4\%9fretim\%20ve.pdf?sequence=1\&isAllow $\underline{\mathrm{ed}=\mathrm{y}}$

Amado Martins, J., Negrao Baptista, R., Dias Countinho, V., Domingues Fernandes, M., \& Fernandes, A. (2018). World Health Organization Simulation in nursing and midwifery education. https://doi.org/https://www.euro.who.int/_data/assets/pdf_file/0011/383807/snme-report-eng.pdf?ua=1 Erişim tarihi: 20.06 .2020

Andrea, J., \& Kotowski, P. (2017). Using Standardized Patients in an Undergraduate Nursing Health Assessment Class. Clinical Simulation in Nursing, 13(7), 309-313. https://doi.org/10.1016/j.ecns.2017.05.003

Arseven, A. (2016). Öz Yeterlilik: Bir kavram Analizi. International Periodical for the Languages, Literature and History of Turkish or Turkic, 11(19), 63-80. https://doi.org/https://www.researchgate.net/deref/http\%3A\%2F\%2Fdx.doi.org\%2F10.7827\%2FTurkishStudies .

Association, A. N. (2018). Competency Model. https://doi.org/https://www.nursingworld.org/ 4a0a2e/globalassets/docs/ce/177626-ana-leadership-booklet-newfinal.pdf. Erişim tarihi: 05.11.2020

Ayhan, A., Çekiç, Y., \& Ançel, G. (2018). Psychiatric nursing education: films and reflections. Anatolian Journal of Psychiatry, 19(4), 362-369. https://doi.org/10.5455/apd.285233

Bandura, A. (1977). Self-efficacy: toward a unifying theory of behavioral change. Psychol Rev, 84(2), 191-215. https://doi.org/10.1037//0033-295x.84.2.191

Basak, T., Aciksoz, S., Unver, V., \& Aslan, O. (2019). Using standardized patients to improve the hygiene care skills of firstyear nursing students: A randomized controlled trial. Collegian, 26(1), 49-54. https://doi.org/10.1016/j.colegn.2018.03.005

Bianchi, S., Bernardi, S., Perilli, E., Cipollone, C., Di Biasi, J., \& Macchiarelli, G. (2020). Evaluation of Effectiveness of Digital Technologies During Anatomy Learning in Nursing School. Applied Sciences-Basel, 10(7). https://doi.org/ARTN 2357 10.3390/app10072357

Boztepe, H., \& Terzioğlu, F. (2010). Hemşirelik Eğitiminde Beceri Değerlendirme. Anadolu Hemşirelik ve Sağllk Bilimleri Dergisi, 16(1), 57-64. https://doi.org/https://dergipark.org.tr/en/download/article-file/29621

Carne, B., Kennedy, M., \& Gray, T. (2012). Review article: Crisis resource management in emergency medicine. Emerg Med Australas, 24(1), 7-13. https://doi.org/10.1111/j.1742-6723.2011.01495.x

Choi, Y., Song, E., \& Oh, E. (2015). Effects of teaching communication skills using a video clip on a smart phone on communication competence and emotional intelligence in nursing students. Arch Psychiatr Nurs, 29(2), 90-95. https://doi.org/10.1016/j.apnu.2014.11.003

Coppens, I., Verhaeghe, S., Van Hecke, A., \& Beeckman, D. (2018). The effectiveness of crisis resource management and team debriefing in resuscitation education of nursing students: A randomised controlled trial. J Clin Nurs, 27(1-2), 77-85. https://doi.org/10.1111/jocn.13846

Çonoğlu, G., Özkütük, N., \& Orgun, F. (2020). Hemşirelik Eğitiminde Yenilikçi Eğitim Paradigması: Öğretim Teknolojileriyle Duyuşsal Alanı Harekete Geçirmek. EGE HFD, 36(1), 61-65. https://doi.org/https://dergipark.org.tr/tr/download/article-file/1046708

Dur, S.., \& Mutlu, B. (2018). Otizm Spektrum Bozukluğu ve Hemşirelik Yaklaşımı. Hemşirelikte Eğitim ve Araştırma Dergisi, 15(1), 45-50. https://doi.org/https://www.journalagent.com/kuhead/pdfs/KUHEAD_15_1_45_50.pdf

Durmaz Edeer, A., \& Dicle, A. (2015). Use of Simulation in Nursing Education and Simulation Types. Hemşirelikte Eğitim ve Arassttrma Dergisi, 12(2), 121-125. https://doi.org/10.5222/head.2015.121 
Edmonson, C., Sumagaysay, D., Cueman, M., \& Chappell, S. (2016). The Nurse Leader Role in Crisis Management. J Nurs Adm, 46(9), 417-419. https://doi.org/10.1097/NNA.0000000000000367

Erci, B. (2006). Reliability And Validity Of The Turkish Version Of Generalized Perceived Self-Efficacy Scale. Atatürk Üniversitesi Hemşirelik Yüksek Okulu Dergisi, 9(2), 58-63. https://doi.org/https://dergipark.org.tr/tr/download/articlefile/29311

Erdoğan, Z., \& Bulut, H. (2017). Bilgisayar Destekli Hasta Eğitimi. Gazi Üniversitesi Sağllk Bilimleri Dergisi, 2(3), 13-18. https://doi.org/https://dergipark.org.tr/tr/download/article-file/394893

George, L. E., Locasto, L. W., Pyo, K. A., \& T, W. C. (2017). Effect of the dedicated education unit on nursing student selfefficacy: A quasi-experimental research study. Nurse Educ Pract, 23, 48-53. https://doi.org/10.1016/j.nepr.2017.02.007

Grimm, K. L., \& Fowles, E. (2018). Prelicensure Employment and Student Nurse Self-Efficacy. J Nurses Prof Dev, 34(2), 60-66. https://doi.org/10.1097/NND.0000000000000431

Guo, B., Zhao, L., Gao, Y., Peng, X., \& Zhu, Y. (2017). The status of professional identity and professional self-efficacy of nursing students in China and how the medical documentaries affect them: A quasi-randomized controlled trial. Int $J$ Nurs Sci, 4(2), 152-157. https://doi.org/10.1016/j.ijnss.2017.03.006

Guo, Y. F., Zhang, X., Plummer, V., Lam, L., Cross, W., \& Zhang, J. P. (2017). Positive psychotherapy for depression and self-efficacy in undergraduate nursing students: A randomized, controlled trial. Int J Ment Health Nurs, 26(4), 375-383. https://doi.org/10.1111/inm.12255

Henderson, A., Harrison, P., Rowe, J., Edwards, S., Barnes, M., Henderson, S., \& Henderson, A. (2018). Students take the lead for learning in practice: A process for building self-efficacy into undergraduate nursing education. Nurse Educ Pract, 31, 14-19. https://doi.org/10.1016/j.nepr.2018.04.003

Holland, B., Gosselin, K., \& Mulcahy, A. (2017). The Effect of Autogenic Training on Self-Efficacy, Anxiety, and Performance on Nursing Student Simulation. Nurs Educ Perspect, 38(2), 87-89. https://doi.org/10.1097/01.NEP.0000000000000110

Hong, S., \& Yu, P. (2017). Comparison of the effectiveness of two styles of case-based learning implemented in lectures for developing nursing students' critical thinking ability: A randomized controlled trial. Int J Nurs Stud, 68, 16-24. https://doi.org/10.1016/j.ijnurstu.2016.12.008

Iannuzzi, D., Rissmiller, P., Duty, S. M., Feeney, S., Sullivan, M., \& Curtin, C. (2019). Addressing a Gap in Healthcare Access for Transition-Age Youth with Autism: A Pilot Educational Intervention for Family Nurse Practitioner Students. $J$ Autism Dev Disord, 49(4), 1493-1504. https://doi.org/10.1007/s10803-018-3846-9

Jonson, C. O., Pettersson, J., Rybing, J., Nilsson, H., \& Prytz, E. (2017). Short simulation exercises to improve emergency department nurses' self-efficacy for initial disaster management: Controlled before and after study. Nurse Educ Today, 55, 20-25. https://doi.org/10.1016/j.nedt.2017.04.020

Karababa, A., \& DİLmaÇ, B. (2015). Ergenlerde İnsani Değerlerin Sürekli Öfke ve Öfke İfade Biçimlerini Yordamadaki Rolü. Ilköğretim Online, 14(3), 1168-1189. https://doi.org/10.17051/io.2015.85927

Karaçam, Z. (2013). Sistematik Derleme Metodolojisi: Sistematik Derleme Hazırlamak İçin Bir Rehber. DEUHYO ED, 6(1), 26-33. https://doi.org/http://www.deuhyoedergi.org/

Karahan, A., \& Kav, S. (2018). Professional Competency in Nursing. HUHEMFAD-JOHUFON, 5(2), 160-168. https://doi.org/https://orcid.org/0000-0003-0361-7498

Karakoç, F., \& Dönmez, L. (2014). Ölçek Geliştirme Çalışmalarında Temel İlkeler. Tıp Eğitimi Dünyası, 40, 39-49. https://doi.org/https://dergipark.org.tr/tr/download/article-file/199275

Kim, E. (2018). Effect of simulation-based emergency cardiac arrest education on nursing students' self-efficacy and critical thinking skills: Roleplay versus lecture. Nurse Educ Today, 61, 258-263. https://doi.org/10.1016/j.nedt.2017.12.003

Kim, H., \& Suh, E. E. (2018). The Effects of an Interactive Nursing Skills Mobile Application on Nursing Students' Knowledge, Self-efficacy, and Skills Performance: A Randomized Controlled Trial. Asian Nurs Res (Korean Soc Nurs Sci), 12(1), 17-25. https://doi.org/10.1016/j.anr.2018.01.001

Kimhi, E., Reishtein, J. L., Cohen, M., Friger, M., Hurvitz, N., \& Avraham, R. (2016). Impact of Simulation and Clinical Experience on Self-efficacy in Nursing Students: Intervention Study. Nurse Educ, 41(1), E1-4. https://doi.org/10.1097/NNE.0000000000000194

Layous, K., Chancellor, J., Lyubomirsky, S., Wang, L., \& Doraiswamy, P. M. (2011). Delivering happiness: translating positive psychology intervention research for treating major and minor depressive disorders. J Altern Complement Med, 17(8), 675-683. https://doi.org/10.1089/acm.2011.0139

Lee, A., Chan, S. K., \& Fan, L. T. (2015). Stimulation of the wrist acupuncture point PC6 for preventing postoperative nausea and vomiting. The Cochrane database of systematic reviews, 2(11), CD003281. https://doi.org/10.1002/14651858.CD003281.pub4

Lee, H., Min, H., Oh, S. M., \& Shim, K. (2018). Mobile Technology in Undergraduate Nursing Education: A Systematic Review. Healthc Inform Res, 24(2), 97-108. https://doi.org/10.4258/hir.2018.24.2.97 
Mazurek, M. O., Brown, R., Curran, A., \& Sohl, K. (2017). ECHO Autism. Clin Pediatr (Phila), 56(3), 247-256. https://doi.org/10.1177/0009922816648288

McArthur Ravert, P. (2004). Use Of A Human Patient Simulator With Undergraduate Nltrsing Students: A Prototype Evaluation Of Critical Thinking And Self-Efficacy. A dissertation subnlitted to the faculty of The University of Utah in partial fulfillment of the requirements for the degree of Doctor of Philosophy https://doi.org/https://collections.lib.utah.edu/dl_files/0b/c5/0bc55f3e9d9ccdf84be41d056247129722b3d193.pdf

McMullan, M., Jones, R., \& Lea, S. (2011). The effect of an interactive e-drug calculations package on nursing students' drug calculation ability and self-efficacy. Int J Med Inform, 80(6), 421-430. https://doi.org/10.1016/j.ijmedinf.2010.10.021

Moher, D., Hopewell, S., Schulz, K. F., Montori, V., Gotzsche, P. C., Devereaux, P. J., Elbourne, D., Egger, M., Altman, D. G., \& Consort. (2012). CONSORT 2010 explanation and elaboration: updated guidelines for reporting parallel group randomised trials. Int J Surg, 10(1), 28-55. https://doi.org/10.1016/j.ijsu.2011.10.001

Moher, D., Liberati, A., Tatzlaff, J., \& Altman, D. (2009). Preferred Reporting Items for Systematic Reviews and MetaAnalyses: The PRISMA Statement. PLoS Med., 7(https://journals.plos.org/plosmedicine/article?id=10.1371/journal.pmed.1000097), Erişim tarihi: 19.05.2019.

Pınar, G., Akalın, A., \& Abay, A. (2016). The Effect Of Video Based Simulation Training On Neonatal Examination Competency Among Turkish Nursing Students. European Scientific Journal, 12(15), 394-406. https://doi.org/0.19044/esj.2016.v12n15p394

PRISMA. http://www.prisma-statement.org/. Erişim tarihi: 25.04.2019.

RCT. (2018). https://casp-uk.net/wp-content/uploads/2018/03/CASP-Randomised-Controlled-Trial-Checklist2018_fillable_form.pdf. Erişim tarihi: 12.01.2019.

Reljic, N., Lorber, M., Vrbnjak, D., Sharvin, B., \& Strauss, M. (2017). Assessment of Clinical Nursing Competencies: Literature Review. Teaching and Learning in Education, Chep, 50-70. https://doi.org/http://dx.doi.org/10.5772/67362

Rowbotham, M., \& Owen, R. M. (2015). The effect of clinical nursing instructors on student self-efficacy. Nurse Educ Pract, 15(6), 561-566. https://doi.org/10.1016/j.nepr.2015.09.008

Schwarzer, R., \& Schroder, K. (1997). Effects of self-efficacy and social support on postsurgical recovery of heart patients. Irish Journal of Psychology, 18(1), 88-103. https://doi.org/Doi 10.1080/03033910.1997.10558131

Shinnick, M. A., \& Woo, M. A. (2014). Does Nursing Student Self-efficacy Correlate with Knowledge When Using Human Patient Simulation? Clinical Simulation in Nursing, 10(2), e71-e79. https://doi.org/10.1016/j.ecns.2013.07.006

Stayt, L. C., Merriman, C., Ricketts, B., Morton, S., \& Simpson, T. (2015). Recognizing And Managing A Deteriorating Patient: A Randomized Controlled Trial Investigating The Effectiveness Of Clinical Simulation In Improving Clinical Performance In Undergraduate Nursing Students. J Adv Nurs, 71(11), 2563-2574. https://doi.org/10.1111/jan.12722

TDK. Türkçe Sözlük. https://doi.org/https://sozluk.gov.tr/. Erişim tarihi: 05.11.2020

Tekin, Ö. (2015). Kriz Yönetimi ve Kamu Yönetimi İçin Önemi. Selçuk Üniversitesi Sosyal Bilimler Meslek Yüksekokulu Dergisi, 18(2), 119-135. https://doi.org/http://sbmyod.selcuk.edu.tr/sumbtd/article/view/330/301

The Joanna Briggs, İ. (2017). Checklist for Randomized Controlled Trials. Joanna Briggs Institude, https://joannabriggs.org/sites/default/files/2019-05/JBI_RCTs_Appraisal_tool2017_0.pdf(Erişim tarihi:23.05.2019).

Unver, V., Basak, T., Watts, P., Gaioso, V., Moss, J., Tastan, S., Iyigun, E., \& Tosun, N. (2017). The reliability and validity of three questionnaires: The Student Satisfaction and Self-Confidence in Learning Scale, Simulation Design Scale, and Educational Practices Questionnaire. Contemp Nurse, 53(1), 60-74. https://doi.org/10.1080/10376178.2017.1282319

Uslu, Y., \& Yavuz van Gierberger, M. (2019). Hemşirelik Eğitiminde Standardize Hasta Kullanımı. Kastamonu Ĕ̈itim Dergisi, 27(1), 271-280.

https://doi.org/https://www.researchgate.net/deref/http\%3A\%2F\%2Fdx.doi.org\%2F10.24106\%2Fkefdergi.2521

van Hooft, S. M., Becque, Y. N., Dwarswaard, J., van Staa, A., \& Bal, R. (2018). Teaching self-management support in Dutch Bachelor of Nursing education: A mixed methods study of the curriculum. Nurse Educ Today, 68, $146-152$. https://doi.org/10.1016/j.nedt.2018.06.005

Vanaki, Z., Nehrir, B., Mokhtari Nouri, J., Khademolhosseini, S. M., \& Ebadi, A. (2016). Competency in Nursing Students: A Systematic Review. International Journal of Travel Medicine and Global Health, 4(1), 3-11. https://doi.org/10.20286/ijtmgh-04013

Vizeshfar, F., \& Torabizadeh, C. (2018). The effect of teaching based on dominant learning style on nursing students' academic achievement. Nurse Educ Pract, 28(2018), 103-108. https://doi.org/10.1016/j.nepr.2017.10.013

Zartman, R. R., McWhorter, A. G., Seale, N. S., \& Boone, W. J. (2002). Using OSCE-Based Evaluation: Curricular Impact over Time. Journal of Dental Education, 66(12), 1323-1330. https://doi.org/10.1002/j.0022-0337.2002.66.12.tb03605.x

Zhang, Z.-J., Zhang, C.-L., Zhang, X.-G., Liu, X.-M., Zhang, H., Wang, J., \& Liu, S. (2015). Relationship between selfefficacy beliefs and achievement motivation in student nurses. Chinese Nursing Research, 2(2-3), 67-70. https://doi.org/10.1016/j.cnre.2015.06.001 


\section{EXTENDED ABSTRACT}

Introduction: Competence in an area is referred to as efficacy. Self-competence means self-efficacy. Self-efficacy is either used to mean something in general or to express different types of efficacy (academic, professional, general, etc.). Studies address different types of efficacy in nursing students. Nurses should have high self-efficacy, which should be evaluated as of undergraduate years. In order for the nursing students to graduate as professionally competent nurses, it must be ensured that they are professionally competent before graduation. Studies show that different teaching methods can be used to help nursing students develop self-efficacy in different areas. Therefore, evaluating teaching methods and their outcomes is essential to help nursing students develop professional skills.

Purpose: This study addressed randomized controlled trials (RCT) on efficacy in nursing students to determine the teaching methods used to increase their self-efficacy and the measurement tools used to evaluate it. The research question was, "What teaching methods are used to help nursing students develop self-efficacy, and what measurement tools are used to evaluate it?"

Materials and Methods: This study is a review study. The PRISMA statement was used to develop the protocol and write the article, and the CONSORT 2010 checklist was used to review articles methodologically. Both researchers conducted a literature review, selected articles, extracted data, and evaluated article quality independently of each other to reduce bias. To this end, a data extraction tool was created by the researchers and the studies included in the research were examined in terms of method, sample size, determination of sample size, place and year of research, teaching method applied to improve competence, results, and recommendations. After each researcher evaluated the articles separately with these lists, the data were combined. The researchers reached a consensus on the articles to be included in the scope of the study.

Prior to the screening, the two researchers conducted a pilot search on SCIENCE DIRECT using the keyword "teaching method" and extracted data from three articles and evaluated their quality. They screened Turkish and English databases between 1 March and 1 May 2019 for relevant articles published from 2010 to 2019. They used the keywords of "teaching method," "efficacy," "effectiveness," "nursing student," and "student nurse" for English databases, while they used the keywords of "öğrenme yöntemleri," (teaching method) "yeterlik" (efficacy), "etkinlik" (effectiveness), "hemşirelik öğrencisi" (nursing student), and "ögrenci hemşire" (student nurse). The researchers conducted literature reviews on the databases of EBSCO, CINAHL, EMBASE, COCHRANE, MEDLINE/PUBMED, PsycINFO /PROQUEST, SCIENCE DİRECT, ULAKBIM, DergiPark, and Google Scholar. The inclusion criteria were; (1) randomized controlled trial, (2) having performed an intervention to help nursing students develop self-efficacy, (3) having measured self-efficacy using an assessment tool after the intervention, (4) published in English or Turkish, (5) published between 1 March and 1 May 2019, (6) accessible full-text articles. The studies included in the study were evaluated methodologically by both researchers, using the Turkish text of the evaluation list consisting of 11 questions. Scoring was not done because the evaluation was not recommended by giving scores according to this list.

Findings: The literature review yielded 104.456 articles. The researchers used the data extraction tool first to examine the titles, then the abstracts, and then the methods and results of the articles. A total of 131 articles were relevant. After a detailed evaluation, the number of articles was reduced to 19. Nine of them did not meet the inclusion criteria, and therefore, the sample consisted of ten articles. The reasons for not including the articles were that they included participants who were not only nursing students; there were deficiencies in terms of RKD and CONSORT data; the articles included a published study protocol; and different evaluations other than student competence were made in the studies. Eight teaching methods and eight assessment tools were used in the selected ten articles. The teaching methods were standard patient, simulator, crisis resource management training, positive psychotherapy, and technology (smartphones, online training programs, domainspecific electronic learning programs, and documentaries). The measurement tools were the student satisfaction and selfconfidence in learning scale (SCLS), general self-efficacy scale, professional self-efficacy scale, nursing competence selfefficacy scale, autism self-efficacy scale, field-focused self-efficacy (OSCE), medication preparation self-efficacy scale, and cardiac self-efficacy scale.

Conclusion and Suggestions: It is vital to measure and evaluate education. Measuring means obtaining a numerical result while evaluating means interpreting that numerical result. Academic performance should be evaluated together with social-psychological and general status, and progress of events. Assessment tools are used to rank and classify domain-specific skills. Measurements in applied areas produce more accurate evaluations, allowing us to see what is right, what is wrong, and what is missing. In addition, the results pertaining to the competencies of the students can contribute to the updating of the nursing education program within the framework of the requirements. It can be recommended that the measurement tools which were used in this review without validity and reliability measures should be used after carrying out Turkish validityreliability studies. It may further be recommended to conduct new studies by applying the teaching methods used in the reviews in different fields of nursing and to develop new measurement tools in order to evaluate students' professional skills. 